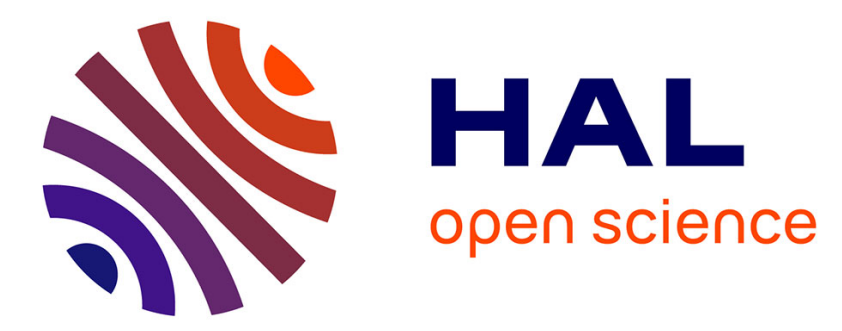

\title{
Species boundaries in the Himantura uarnak species complex (Myliobatiformes: Dasyatidae)
}

Irma S. Arlyza, Kang-Ning Shen, Dedy Duryadi Solihin, Dedi Soedharma, Patrick Berrebi, Philippe Borsa

\section{- To cite this version:}

Irma S. Arlyza, Kang-Ning Shen, Dedy Duryadi Solihin, Dedi Soedharma, Patrick Berrebi, et al.. Species boundaries in the Himantura uarnak species complex (Myliobatiformes: Dasyatidae). Molecular Phylogenetics and Evolution, 2013, 66, pp.429-435. 10.1016/j.ympev.2012.09.023 . ird-00758049

\section{HAL Id: ird-00758049 \\ https://hal.ird.fr/ird-00758049}

Submitted on 28 Nov 2012

HAL is a multi-disciplinary open access archive for the deposit and dissemination of scientific research documents, whether they are published or not. The documents may come from teaching and research institutions in France or abroad, or from public or private research centers.
L'archive ouverte pluridisciplinaire HAL, est destinée au dépôt et à la diffusion de documents scientifiques de niveau recherche, publiés ou non, émanant des établissements d'enseignement et de recherche français ou étrangers, des laboratoires publics ou privés. 
Arlyza I.S., Shen K.-N., Solihin D.D., Soedharma D., Berrebi P., Borsa P. (2013) Species boundaries in the Himantura uarnak species complex (Myliobatiformes: Dasyatidae). Mol. Phyl. Evol. 66, 429-435.

\section{Species boundaries in the Himantura uarnak species complex (Myliobatiformes: Dasyatidae)}

I.S. Arlyza a,b, K.-N. Shen c, D.D. Solihin ${ }^{b}$, D. Soedharma ${ }^{\text {b }}$, P. Berrebi ${ }^{d}$, P. Borsa ${ }^{*}$

a Lembaga Ilmu Pengetahuan Indonesia (LIPI), Pusat Penelitian Oseanografi (P2O), Jakarta, Indonesia

b Institut Pertanian Bogor, Bogor, Indonesia

c Department of Environmental Biology and Fisheries Science, National Taiwan Ocean University, Keelung, Taiwan

d Institut des sciences de l'évolution à Montpellier (ISE-M), UMR 5554 UM2-CNRS-IRD, Université Montpellier 2, Montpellier, France

e Institut de recherche pour le développement (IRD), UR 227 "Biocomplexité des écosystèmes récifaux", Montpellier, France

* Corresponding author, present address: Indonesian Biodiversity Research Center, Universitas Udayana, Jl Sesetan Gang Markisa 6, Denpasar, Indonesia. E-mail: philippe.borsa@ird.fr (P. Borsa) 

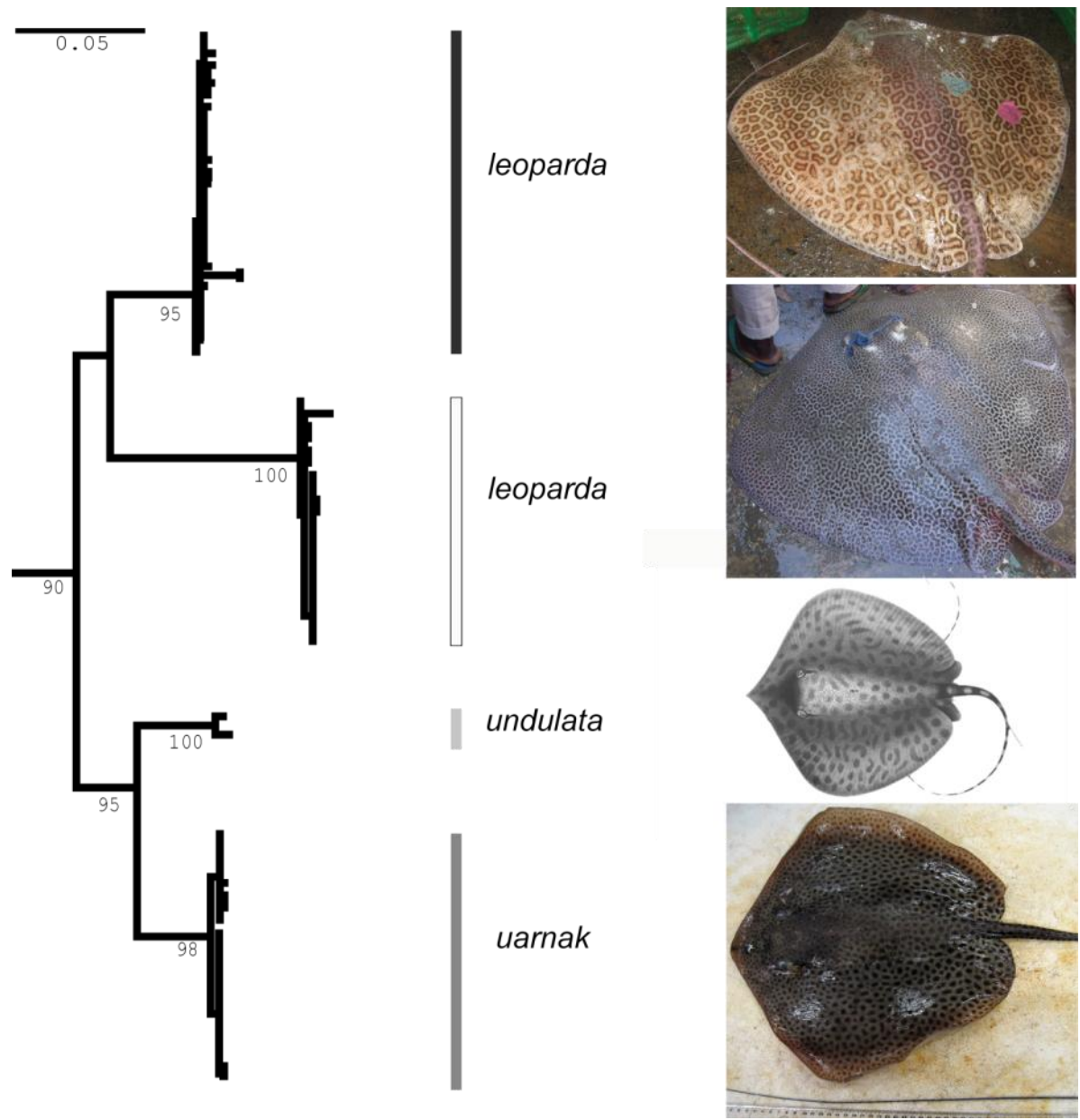

\section{Highlights}

- Stingrays of the Himantura narnak species complex were sampled throughout the Indo-West Pacific.

- Four reproductively isolated entities were detected by nuclear markers.

- Cryptic species were detected within the recently-described $H$. leoparda

- Four mitochondrial clades were uncovered, each specific to a species 


\begin{abstract}
Samples of the 'Himantura narnak' species complex (H. leoparda, H. narnak, H. undulata under their current definitions), mostly from the Coral Triangle, were analyzed using nuclear markers and mitochondrial DNA sequences. Genotypes at five intron loci showed four reproductively isolated clusters of individuals. The COI sequences showed four major mitochondrial lineages, each diagnostic of a cluster as defined by nuclear markers. No mitochondrial introgression was detected. The average Kimura-2 parameter nucleotide distance separating clades was 0.061-0.120 (net: 0.055-0.114), while the distance separating individuals within a clade was $0.002-0.008$. Additional, partial cytochrome- $b$ gene sequences were used to link these samples with previously published sequences of reference specimens of the three nominal species. One of the clusters was identified as $H$. undulata and another one, as H. uarnak, while two cryptic species were uncovered within the recently-described $H$. leoparda, challenging the current morphologybased taxonomy of species within the H. uarnak species complex.
\end{abstract}

Keywords: intron-size polymorphism, cytochrome oxidase I, cytochrome $b$, phylogeny, cryptic species, taxonomy, DNA barcoding

\title{
1. Introduction
}

Taxonomic accuracy is fundamental for correctly identifying species, hence for assessing their habitats and distributions, which in turn is important to conservation and fisheries management. Within the last two decades, much concern has been expressed regarding the conservation status of elasmobranchs (Stevens et al., 2000; Garcia et al., 2008; Lam and Sadovy de Mitcheson, 2011; White and Kyne, 2010). Elasmobranchs generally mature slowly and have low fecundity (Stevens et al., 2000).

Shallow-water, bottom-dwelling elasmobranch species are particularly at risk of extinction because of their exposure to overfishing. This includes stingrays (Myliobatiformes: Dasyatidae), which are subject to intensive and unregulated exploitation in Southeast Asia (Blaber et al., 2009; White and Kyne, 2010) and elsewhere. As a consequence, several stingray species from the Australasian region are now listed as vulnerable (White and Kyne, 2010).

Molecular surveys conducted for the fish-Barcode of Life project have helped flagging cryptic species in stingrays (Last and White, 2008), underlining a still-incomplete taxonomy of species in the family. About one third of the species in the family Dasyatidae belong to the genus Himantura (25 species in this genus, some of them still undescribed; Manjaji, 2004; Last et al. 2008). Himantura species are widely distributed in the marine, brackish, and freshwater habitats of the tropical and subtropical Atlantic, Indian and Pacific Oceans (Manjaji, 2004). Here, we focus on stingrays of the 'Himantura narnak' species complex, which have received recent attention from morphological taxonomists. Species of the H. narnak species complex have often been confused with one another, as all have a "similar overall disc shape and a dorsal disc pattern consisting of large spots in juveniles that form a complex pattern of spots, reticulations and/or ocelli in adults" (Manjaji-Matsumoto and Last, 2008). Four species are currently recognized in this group (Eschmeyer, 2012): H. fava (Annandale, 1909), H. leoparda (Manjaji-Matsumoto and Last, 2008), H. uarnake (Forsskål, 1775) and H. undulata (Bleeker, 1852). However, Manjaji-Matsumoto and Last (2008) consider $H$. fava as a junior synonym of $H$. undulata.

Taxonomic confusion may arise when morphological characters used to define species overlap. This may occur, in particular, between pairs of species that hybridize (e.g. Borsa and Quignard, 2001). Because fertilization in elasmobranchs is internal, hybridization is likely to be mostly absent in this group (Ward et 
al., 2008; Dudgeon et al., 2012). The recent report of hybridization in a whaler shark species (Morgan et al., 2012) might be an exception.

The objectives of the present work were: (1) to investigate the phylogenetic species boundaries in the H. uarnak species complex, and clarify the systematics of this group using both mitochondrial and nuclear markers; (2) to assess the reliability of molecular markers for identification purposes in this group.

\section{Materials and methods}

Tissue samples of 115 individuals of the Himantura narnak species complex were collected from Zanzibar, from Taiwan, and from 8 fish landing sites throughout Indonesia (Table 1). The tissue samples consisted of $0.01-0.5 \mathrm{~cm} 3$ of skin or flesh or tail extremity, dissected with surgical scissors and preserved in 90\%-96\% ethanol. DNA was extracted using the DNEasy ${ }^{\circledR}$ Tissue Kit (Qiagen GmbH, Hilden, Germany). The DNA extracts were stored at $-30^{\circ} \mathrm{C}$ until required for laboratory analyses.

The individuals sampled were genotyped at a total of 5 size-polymorphic intron loci, which were scored using the exon primer pairs (Act-2-F, Act-2-R) and (Cam-3-F, Cam-3-R) (Atarhouch et al., 2003) following the approach and protocols detailed in Borsa et al. (in press). Annealing temperatures were $54^{\circ} \mathrm{C}$ for the amplification of the two $A c t-2$ introns and $55^{\circ} \mathrm{C}$ for that of the three Cam-3 introns.

A 620-bp fragment of the mitochondrial cytochrome oxidase I (COI) gene was amplified by polymerase chain reaction (PCR) using the FishF1 and FishR1 primers of Ward et al. (2005). PCR amplifications were performed in $50 \mu \mathrm{L}$ reaction mixture containing $25 \mu \mathrm{L} 2 \mathrm{X}$ ReadyMix KapaTaq DNA polymerase mix (0.05 U/ $\mu \mathrm{L}, 3 \mathrm{mM} \mathrm{Mg}{ }^{2+}, 0.4 \mathrm{mM}$ each dNTP) (Kapa Biosystems, Boston, U.S.A.), $1 \mu \mathrm{L}$ $0.2 \mu \mathrm{M}$ of each primer (1 1 st BASE, Singapore), $2 \mu \mathrm{L}$ DNA template and $21 \mu \mathrm{L}$ water (Qiagen). In addition, a 420-bp fragment of the mitochondrial cytochrome $b(c y t b)$ gene was similarly PCR-amplified using primers GLU1L and CB2H of Sezaki et al. (1999). The PCR mix was the same as for COI, except that primer concentration was quadrupled. Cycling parameters were an initial denaturation at $95^{\circ} \mathrm{C}$ for 2 min followed by 35 cycles of denaturation $\left(95^{\circ} \mathrm{C}\right.$ for $\left.30 \mathrm{~s}\right)$, annealing $\left(53^{\circ} \mathrm{C}\right.$ for $\left.30 \mathrm{~s}\right)$, and extension $\left(72^{\circ} \mathrm{C}\right.$ for $\left.1 \mathrm{~min}\right)$ with the final extension step at $72^{\circ} \mathrm{C}$ for $2 \mathrm{~min}$ in an Applied Biosystems (Foster City, CA, U.S.A.) VeritiTM thermocycler. PCR-amplified DNAs were visualized on 1\% agarose gels. Prior to sequencing, excess dNTPs and oligonucleotides were eliminated from the PCR product using shrimp alkaline phosphatase and exonuclease I (Exo-SAP-IT kit; Affymetrix, Santa Clara CA, U.S.A.) following the manufacturer's protocol. Sequence reactions were performed in both directions using the BigDye terminator v3.1 cycle sequencing kit (Applied Biosystems), 8-10 $\mu \mathrm{L}$ purified PCR product, and 4-5 $\mu \mathrm{L}$ of either primer $(3 \mu \mathrm{M})$ per reaction. Sequence-reaction products were loaded into an ABI 3130xl automated sequencer (Applied Biosystems) at the Hawaii Institute of Marine Biology EPSCoR sequencing facility. Forward and reverse sequences were proofread, aligned and edited using MEGA 5 (Tamura et al., 2011) and BIOEDIT (Hall, 1999). Edited sequences were deposited in GENBANK (http://www.ncbi.nlm.nih.gov/).

Correspondence analysis (Benzécri, 1982) implemented in GENETIX 4.02 (Belkhir et al., 2000) was performed to visualize clusters of individuals characterized by their genotypes at 5 polymorphic intron loci, by reducing the multidimensional allelic frequency space to a bidimensional space. Hardy-Weinberg equilibrium and two-locus linkage equilibrium were tested using random permutations under GENETIX. Bayesian structure analysis (STRUCTURE 2.3.1; Falush et al., 2007) was used to delineate clusters of individuals by determining the number of populations present in the total sample of the Himantura uarnak. species complex and assigning individuals to these populations using the model-based program. The Markov-Chain Monte Carlo algorithm was run under the admixture model with correlated allele frequencies for 100,000 steps after 50,000 initial burn-in steps, without any a priori information on an 
individual's sampling location, to estimate individual admixture proportions and assign individuals to populations. Five independent runs were performed (to check the stability of the assignation among runs) for each number of populations ( $K$, ranging from 3 to 5 ) to determine the number of populations a posteriori by visually comparing the output diagrams.

The COI sequence dataset comprised 114 ingroup sequences and 27 outgroup sequences aligned over 620 bp. All new sequences were deposited in GENBANK under accession nos. JX263306-JX263424. The best substitution model according to the Bayesian information criterion (MEGA5) was HKY $+\mathrm{G}+\mathrm{I}$ and this model was used to produce a maximum-likelihood (ML) phylogeny of the COI sequences. The cytb sequence dataset comprised 130 ingroup sequences, including 14 sequences (239 bp) from Manjaji (2004) here used as references, new sequences deposited in GENBANK (JX274304- JX274334), and one outgroup sequence (H. signifier, Manjaji, 2004), aligned over 239 bp. Twelve specimens of the Himantura narnak species complex that were analyzed here belong to museum collections (Table 1). For ML analysis of the $c y t b$ dataset, the best substitution model according to the Bayesian information criterion (MEGA5) was $\mathrm{K} 2+\mathrm{G}$. In both phylogenetic treatments, nodal support was assessed by bootstrapping (Felsenstein, 1985), based on 1000 pseudo-replicates.

\section{Results}

Four main clusters of individuals ('Clusters' 1-4: Fig. 1) were detected from correspondence analysis of multiple-locus nuclear genotypes (matrix of genotypes presented as Supplementary material, Table S1). Three of them $(1,3,4)$ were also detected from Bayesian structure analysis.

Four outliers were observed, including three individuals (ir024, ir037 and ir083) positioned between Cluster 1 and Cluster 3 and one individual (ir053) positioned between Cluster 1 and Cluster 4 (Fig. 1). Their proportion in the total sample was $4 / 109$, using as denominator of this ratio the number of individuals genotyped at all 5 nuclear loci (Supplementary material, Table S1). Individuals ir024, ir037, and ir083 were doubly heterozygous for alleles quasi-diagnostic between Cluster 1 and Cluster 3 at the two loci (Cam-3 A and Cam-3 B) that differentiate these two clusters, whereas individual ir053 was doubly heterozygous for alleles quasi-diagnostic between Cluster 1 and Cluster 4 at 2/4 loci that differentiate the two latter clusters (Supplementary material, Table S1). Let us include into Cluster 1 those three individuals that possess Clade- $I$ mitochondria and which were classed as intermediate between Cluster 1 and Cluster 3 by correspondence analysis (Fig. 1). The frequencies of alleles Cam-3 $A^{175}$ and Cam-3 B ${ }^{165}$ in Cluster 1 as defined here were, respectively, 0.089 and 0.107 . Under the hypothesis of panmixia and linkage equilibrium, the expected frequencies of the heterozygotes would be, respectively, 0.163 and 0.191 , and the expected frequency of the double-heterozygotes would be 0.031 . Here, the actual frequencies of the heterozygotes were, respectively, $5 / 28=0.179$ and $6 / 28=0.214$ (not significantly above the expectations from panmixia). However, the frequency of double-heterozygotes was $3 / 28=0.107$ which is three times more than the expected frequency. The linkage disequilibrium between the two loci was $D=0.032$ and its associated probability (Black and Krafsur, 1985) was $P=0.079$. So, the hypothesis of non random association of alleles at the two loci was somewhat supported by the data, although the null hypothesis of linkage equilibrium could not be formally rejected either.

If this linkage disequilibrium is real, a sensible explanation for it is hybridization between the two species, where Cam-3 $A^{175}$ - Cam-3 $B^{165}$ di-locus haplotypes are introduced from Cluster 3 into Cluster 1, which is characterized by Cam-3 $A^{178}-$ Cam-3 $B^{163}$ haplotypes. We assume that the effective population size of Himantura Cluster 1 is large enough to neglect the eventuality that linkage disequilibrium be caused by genetic drift and we discard the eventuality that linkage disequilibrium between $\mathrm{Cam}_{-3} \mathrm{~A}$ and $\mathrm{Cam}-3 \mathrm{~B}$ 
arose by mutation at either one of the two loci. Another possibility for creating linkage disequilibrium is selection. The selection hypothesis would suppose some epistasy between the two intron loci (this is unlikely) or between loci closely linked to them, but then, one has to provide an explanation for the linkage disequilibrium between the two intron loci and the two putatively selected loci. Therefore, hybridization remains the most likely explanation and in this case, the three Clade-I outliers might be F1 hybrids. Similar reasoning leads to suspecting Individual ir053 (the single Clade-IV outlier) of possibly being a Cluster 4 x Cluster 1 backcross offspring. An alternative explanation would be shared polymorphism between the species, and the putative excess of double-heterozygotes in Cluster 1 would be caused by residual physical linkage between the two loci examined. This would imply that recombination between the two loci within a species would be slower than allele sorting between the two species, which is hard to conceive.

The ML phylogeny of mitochondrial lineages, based on partial COI gene sequences (Fig. 2) supported the monophyly of the H. uamak species complex. The ingroup haplotypes were clustered into four main clades (I-IV) (Fig. 2). Clades were separated by an estimated 0.061-0.120 (net: 0.055-0.114) nucleotide distance (Kimura-2 parameter distance; MEGA5). Intra-clade nucleotide diversity was comparatively low (0.002-0.008). Clusters $1-4$ were characterized by mitochondrial Clades $I-I V$, respectively (Fig. 1), with no mismatch observed. Albeit less resolved, the phylogeny based on $c y t b$ sequences (Fig. 3) provided the taxonomic information necessary to identify to species each of the previously defined Clusters (1-4), from the placement of reference specimens (Table 1). Clade II included sequences of reference $H$. undulata specimens and Clade III included those of $H$. uarnak (Fig. 3). Both Clades $I$ and $I V$ clustered with sequences of reference $H$. leoparda specimens. This included, respectively, specimens CSIRO H5284.05 and CSIRO H5478.01, both chosen as paratypes of H. leoparda by ManjajiMatsumoto and Last (2008).

Thus, both Cluster 1 and Cluster 4 were identified as H. leoparda under its current definition, Cluster 2 was unambiguously identified as $H$. undulata and Cluster 3 was identified as H. uarnak. The outliers on Fig. 1 possessed the mitochondrial haplotype of the cluster geometrically closest to them.

\section{Discussion}

The present results challenge the current perception of species boundaries in the Himantura narnake species complex, which are based on morphology (Manjaji-Matsumoto and Last, 2008).

Four distinct clusters of individuals defined by their multiple-locus genotypes were observed within the $H$. uarnak species complex. Each cluster was further characterized by a distinct mitochondrial clade, and no mitochondrial introgression was observed between clusters. Although some putative hybridization between clusters was inferred from the observation of heterozygous individuals interpreted as possible hybrids and/or backcross offspring, their low proportion $(<4 \%)$ demonstrates that hybridization, if it actually occurs, is likely to occur only rarely. Thus, genetic homogeneity across large geographic distances (Table 1) is maintained within each cluster despite the eventuality of inter-cluster crosses. These observations altogether demonstrate the genetic isolation or quasi-isolation of the four clusters from one another, hence the occurrence of four biological species within the H. uarnak species complex. One of these species was $H$. uarnak, another one was $H$. undulata, while two cryptic species were uncovered within H. leoparda under its current definition. Considering that the two latter are sympatric over a broad geographic area, the low incidence of possible hybrids and back-crossed individuals, if confirmed, would not call into question their full qualification as biological species (Mayr, 1942). 
The specimen identified as $H$. fava (Table 1), represented by a COI sequence deposited in the Barcoding of Life Database (http:/ / bins.boldsystems.org) was here identified as H. undulata, supporting Manjaji (2004) who had since then synonymised the two species. Manjaji-Matsumoto and Last (2008) chose as paratypes of $H$. leoparda two individuals whose mitochondrial haplotypes indicate that they belong to different species. As no genetic data are currently available to determine the mitochondrial haplogroup of the holotype of H. leoparda (CSIRO H2903.01), it is not possible from the present results to determine which of Clusters 1 or 4 is the actual H. leoparda. Manjaji (2004) mentioned that two forms co-occurred within her Himantura sp. A (now H. leoparda) samples based on spotting patterns: a typical leopard-like spotted form and an atypical form with finer spots. Further research is warranted to determine whether differences in spotting patterns coincide with the distinction of the two cryptic species.

Given the continued confusion in the morphology-based taxonomy of species within the H. uarnak species complex, which contrasts with the sharp distinction provided by the partial COI sequences (present work), we advocate the use of the universal COI marker for species identification (Ward et al., 2008; 2009) in this group. Moreover, notwithstanding eventual rare cases of mitochondrial introgression, which yet would remain to be documented, it is sensible to propose that the COI marker be used as diagnostic character in a future taxonomic revision of the H. narnak species complex.

If at all occurring, the rarity of individuals with mixed-species ancestry in the H. narnak species complex supports the general view that hybridization is a rare phenomenon in elasmobranchs (Ward et al., 2008; Dudgeon et al., 2012). Since the species in the H. uarnak species complex have overlapping geographic ranges (Table 1) and share habitats, one suspects isolating mechanisms to operate. We speculate that interspecific differences in male clasper distal length and shape (Manjaji, 2004) and possible matching differences in the morphology of the female urogenital sinus may contribute to preventing successful mating between species in the $H$. uarnak species complex.

\section{Acknowledgements}

We are grateful to W.-J. Chen, J.-D. Durand, H.-C. Ho and A. Prasetyo for participating in the collection of samples; ; to B. Wainwright for his help in sequencing; and to R. Bills, L. Carassou and R. Hadiaty for providing information on some of the voucher specimens. We are grateful to an anonymous reviewer for insightful comments on a former version of this paper. Designed the study: P Borsa. Contributed reagents or materials or analysis tools: ISA, KNS, P Berrebi, P Borsa. Performed the experiments: ISA, KNS. Analyzed and interpreted the data: P Berrebi, P Borsa. Wrote the paper: P Borsa. ISA benefitted from an AIRD-BEST 6-months fellowship to conduct experiments at P Berrebi's laboratory in Montpellier. Funded by AIRD, IRD UR227, ISE-M, LIPI-P2O, and National Taiwan University-Institute of Fisheries Science; the funders had no role in study design, data collection and analysis, decision to publish, or preparation of the manuscript.

\section{References}

Adrim, M. 2008. Studi biodiversitas hiu dan pari di Indonesia. Laporan proyek kompetitif, LIPI-P2O, Jakarta, 59 pp.

Annandale, N., 1909. Report on the fishes taken by the Bengal fisheries steamer 'Golden Crown'. Part I, Batoidei. Mem. Indian Mus. 2, 1-60.

Atarhouch, T., Rami, M., Cattaneo-Berrebi, G., Ibanez, C., Augros, S., Boissin, E., Dakkak, A., Berrebi, P., 2003. Primers for EPIC amplification of intron sequences for fish and other vertebrate population genetic studies. Biotechniques 35, 676-682. 
Belkhir, K., Borsa, P., Chikhi, L., Raufaste, N., Bonhomme, F., 2000. GENETIX version 4.02, logiciel sous Windows ${ }^{\mathrm{TM}}$ pour la génétique des populations. CNRS UMR 5000, Université Montpellier 2, Montpellier (http://www.genetix.univmontp2.fr/genetix/).

Benzécri, J.-P., L’analyse des données, 2, L’analyse des correspondances, Dunod, Paris, 1982.

Blaber, S.J.M., Dichmont, C.M., White, W., Buckworth, R., Sadiyah, L., Iskandar, B., Nurhakim, S., Pillans, R., Andamari, R., Dharmadi, Fahmi, 2009. Elasmobranchs in southern Indonesian fisheries: the fisheries, the status of the stocks and management options. Rev. Fish Biol. Fisheries 19, 367-391.

Black, W.C.4, Krafsur, E.S. 1985. A FORTRAN program for the calculation and analysis of two-locus linkage disequilibrium coefficients. Theor. Appl. Genet. 70, 491-496.

Bleeker, P., 1852. Bijdrage tot de kennis der Plagiostomen van den Indischen Archipel. Verhandelingen van het Bataviaasch Genootschap van Kunsten en Wettenschappen 24, 1-92.

Borsa P., Arlyza I.S., Laporte M., Berrebi P. (in press) Population genetic structure of the blue-spotted maskray Neotrygon kublii and two other Indo-West Pacific stingray species (Myliobatiformes: Dasyatidae), inferred from size-polymorphic intron markers. J. Exp. Mar. Biol. Ecol. doi: 10.1016/j.jembe.2012.09.010

Borsa, P., Quignard, J.-P., 2001. Systematics of the Atlantic-Mediterranean soles Pegusa impar, P. lascaris, Solea aegyptiaca, S. senegalensis, and S. solea (Pleuronectiformes: Soleidae). Can. J. Zool. 79, 2297-2302.

Dudgeon C.L., Blower D.C., Broderick D., Giles J.L., Holmes B.J., Kashiwagi T., Krück N.C., Morgan J.A.T., Tillett B.J., Ovenden J.R. 2012. A review of the application of molecular genetics for fisheries management and conservation of sharks and rays. J. Fish Biol. 80, 1789-1843.

Eschmeyer, W.N. (ed.) 2012. Catalog of Fishes, electronic version (http://research.calacademy.org/research/ichthyology/catalog/fishcatmain.asp; 30 June 2012).

Falush, D., Stephens, M., Pritchard, J., 2007. Inference of population structure using multilocus genotype data: dominant markers and null alleles. Mol. Ecol. Resour. 7, 574-578.

Felsenstein, J., 1985. Confidence limits on phylogenies: an approach using the bootstrap. Evolution 39, 783-791.

Forsskål, P., 1775. Descriptiones animalium, avium, amphibiorum, piscium, insectorum, vermium; quae in itinere orientali observavit Petrus Forskål (post mortem auctoris edidit Carsten Niebuhr). Adjuncta est materia medica kahirina atque tabula maris Rubri geographica. Mölleri, Hauniae, xxxiv+164 pp.

Garcia, V.B., Lucifora, L.O., Myers, R.A., 2008. The importance of habitat and life history to extinction risk in sharks, skates, rays and chimaeras. Proc. Roy. Soc. B 275, 83-89.

Hall, T.A., 1999. BIOEDIT: a user-friendly biological sequence alignement editor and analysis program for windows 95/98/NT. Nucl. Acids Symp. Ser. 41, 95-98.

Lam, V.Y.Y., Sadovy de Mitcheson, Y. 2011. The sharks of South East Asia - unknown, unmonitored and unmanaged. Fish Fisheries 12, 51-74.

Last, P.R., White, W.T., 2008. Resurrection of the genus Neotrygon Castelnau (Myliobatoidei: Dasyatidae) with the description of Neotrygon picta sp. nov., a new species from northern Australia. In Last P.R., White W.T., Pogonoski J.J. (eds.) Descriptions of new Australian Chondrichthyans, CSIRO Mar. Atm. Res. Pap. 22. CSIRO, Hobart, 315-325.

Last P.R., White W.T., Pogonoski J.J. (eds.), 2008. Descriptions of new Australian Chondrichthyans, CSIRO Mar. Atm. Res. Pap. 22. CSIRO, Hobart, 358 p.

Manjaji, B.M., 2004. Taxonomy and phylogenetic systematics of the Indo-Pacific whip-tailed stingray genus Himantura Müller and Henle 1837 (Chondrichthyes: Myliobatiformes: Dasyatidae). PhD Thesis, University of Tasmania, xxii+607 pp.

Manjaji-Matsumoto, B.M., Last, P.R., 2008. Himantura leoparda sp. nov., a new whipray (Myliobatoidei: Dasyatidae) from the IndoPacific. In Last P.R., White W.T., Pogonoski J.J. (eds.) Descriptions of new Australian Chondrichthyans, CSIRO Mar. Atm. Res. Pap. 22. CSIRO, Hobart, 293-301.

Mayr, E. 1942. Systematics and the origin of species from the viewpoint of a zoologist. Columbia University Press, New York, 334 p. 
Morgan, J.A.T., Harry, A., Welch, D., Street, R., White, J., Geraghty, P.T., Macbeth, W.G., Broderick, D., Tobin, A., Simpfendorfer, C., Ovenden, J.R. 2012. Detection of interspecies hybridisation in Chondrichthyes: hybrids (hybrid offspring) between Australian (Carcharbinus tilstoni) and common blacktip shark (C. limbatus) found in an Australian fishery. Conserv. Genet. 13, 455-463.

Ratnasingham, S., Hebert, P.D.N. 2007. BOLD: The Barcode of Life Data System (www.barcodinglife.org). Mol. Ecol. Notes 7 , 355-364.

Sezaki, K., Begum, R.A., Wongrat, P., Srivastava, M.P., Kantha, S.S., Kikuchi, K., Ishihara, H., Tanaka, S., Taniuchi, T., Watabe, S. 1999. Molecular phylogeny of Asian freshwater and marine stingrays based on the DNA nucleotide and deduced amino acid sequences of the cytochrome $b$ gene. Fisheries Sci. 65, 563-570.

Stevens, J.D., Bonfil, R., Dulvy, N. K., Walker, P.A., 2000. The effects of fishing on sharks, rays, and chimaeras (chondrichthyans), and the implications for marine ecosystems. ICES J. Mar. Sci. 57, 476-494.

Tamura, K., Peterson, D., Peterson, N., Stecher, G., Nei, M., Kumar, S., 2011. MEGA 5: Molecular evolutionary genetics analysis using maximum likelihood, evolutionary distance, and maximum parsimony methods. Mol. Biol. Evol. 28, 2731-2739.

Ward, R.D., Hanner, R., Hebert, P.D.N., 2009. The campaign to DNA barcode all fishes, FISH-BOL. J. Fish Biol. 74, 329-356.

Ward, R.D., Holmes, B.H., White, W.T., Last, P.R. 2008. DNA barcoding Australian chondrichthyans: results and potential uses in conservation. Mar. Freshw. Res. 59, 57-71.

Ward, R.D., Zemlak, T.S., Innes, B.H., Last, P.R., Hebert, P.D.N. 2005. DNA barcoding Australia's fish species. Phil. Trans. Roy. Soc. Lond. B 360, 1847-1857.

White, W.T., Kyne, P.M. 2010. The status of chondrichthyan conservation in the Indo-Australasian region. J. Fish Biol. 76, 2090_ 2117. 


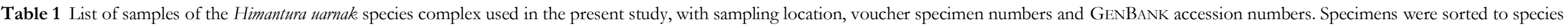

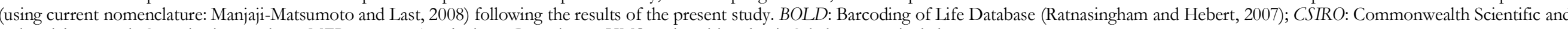
Industrial Research Organisation, Hobart; MZB: Museum Zoologicum Bogoriense; UMS: Universiti Malaysia Sabah, Kota Kinabalu.

\begin{tabular}{|c|c|c|c|c|c|}
\hline \multirow{2}{*}{$\begin{array}{l}\text { Species, } \\
\text { Individual no. }\end{array}$} & \multirow[t]{2}{*}{ Sampling location } & \multirow[t]{2}{*}{ Sampling date } & \multirow[t]{2}{*}{ Voucher } & \multicolumn{2}{|l|}{ GENBANK } \\
\hline & & & & $\mathrm{COI}$ & $c y+b$ \\
\hline \multicolumn{6}{|l|}{ Himantura leoparda a } \\
\hline A1, A4 (Manjaji, 2004) & Kota Kinabalu, South China Sea & 1999 & - & - & - \\
\hline A2 (Manjaji, 2004) & Sandakan, Sulu Sea & 1999 & UMS MMSK [c4] & - & - \\
\hline A6 (Manjaji, 2004) & Kota Kinabalu, South China Sea & 1999 & CSIRO H5284.05 (paratype) & - & - \\
\hline A9 (Manjaji, 2004) & Cochin, Laccadive Sea & 1999 & UMS MMPL11 & - & - \\
\hline zan6 & Zanzibar, W Indian Ocean & May 2010 & - & JX263335 & JX274333 \\
\hline $\begin{array}{l}\text { ir001, ir002, ir005, ir006, ir024, ir026, ir029, ir037, ir043, ir044, } \\
\text { ir045, ir047, ir049, ir052, ir055, ir056, ir073, ir076, ir079-085 }\end{array}$ & Batang, Java Sea d & Jun. 2006-Jan. 2008 & - & JX263306-JX263330 & JX274304-JX274328 \\
\hline ir086, ir088 & Sunda Strait & Oct. 2010 & - & JX263331, JX263332 & JX274329, JX274330 \\
\hline ir112 & Bali Sea & Feb. 2010 & - & JX263333 & JX274331 \\
\hline ir113 & Southern coast of Java off Jogyakarta & Oct. 2010 & - & JX263334 & JX274332 \\
\hline \multicolumn{6}{|l|}{ Himantura leoparda b } \\
\hline A7 (Manjaji, 2004) & Kota Kinabalu, South China Sea & 1999 & CSIRO H5478.01 (paratype) & - & - \\
\hline BOLD TZMSC232-05 'H. uarnak’ & Cape Vidal, Kwazulu-Natal, SW Indian O. & Nov. 2004 & ADC 30.10-1 (tissue voucher) & JF493652 & - \\
\hline BOLD TZMSC474-05 'H. uarnak’ & Cape Vidal, Kwazulu-Natal, SW Indian O. & May 2005 & Smith 30.10-2 & JF493651 & - \\
\hline $\begin{array}{l}\text { ir003, ir004, ir008-023, ir025, ir027, ir028, ir030-036, ir038-042, } \\
\text { ir046, ir048, ir050, ir051, ir053, ir054, ir057-072, ir074, ir075, } \\
\text { ir077, ir078 }\end{array}$ & Batang, Java Sea d & Jun. 2006-Jan. 2008 & - & JX263361- JX263417 & JX274358-JX274416 \\
\hline H. uarnak 1 (Manjaji, 2004) & Kota Kinabalu, South China Sea & 1999 & CSIRO H5476.03 & - & - \\
\hline H. uarnak 2 (Manjaji, 2004) & Kota Kinabalu, South China Sea & 1999 & CSIRO H5477.01 & - & - \\
\hline H. uarnak 3 (Manjaji, 2004) & Semporna, Celebes Sea & 1999 & CSIRO H5484.01 & - & - \\
\hline H. uarnak 6 (Manjaji, 2004) & West Papua & 1999 & EM330 (tissue voucher) & - & - \\
\hline H. uarnak 8 (Manjaji, 2004) & West Papua & 1999 & MMPK7 & - & - \\
\hline wjc 637 & Taiwan, China Sea & 2010 & NMMBP 015601 & JX263360 & JX274357 \\
\hline ir 089-099 & Makassar Strait & Nov. 2009 & - & JX263337-JX263347 & JX274335-JX274345 \\
\hline ir100-106 & Bone Basin off Selayar Island, Banda Sea & Nov. 2009 & MZB 20875 & JX263348-JX263354 & JX274346-JX274352 \\
\hline ir107-109 & Kendari, Banda Sea & Oct. 2010 & - & JX263355-JX263357 & JX274353-JX274355 \\
\hline ir110, ir111 & Labuan Bajo, Flores Sea & Oct. 2010 & - & JX263358-JX263359 & JX274355-JX274356 \\
\hline \multicolumn{6}{|l|}{ Himantura undulata } \\
\hline H. undulata 2 (Manjaji, 2004) & Sipitang, South China Sea & 1999 & CSIRO H5483.01 & - & - \\
\hline H. undulata 3 (Manjaji, 2004) & Sandakan, Sulu Sea & 1999 & CSIRO H5481.01 & - & - \\
\hline BOLD AAF0692 'H. fava' c' & Sandakan, Sulu Sea & April 1996 & BW-A221 (tissue voucher) & DQ108167 & - \\
\hline ir007 & Batang, Java Sea d & Jun. 2006-Jan. 2008 & - & JX263336 & JX274334 \\
\hline
\end{tabular}

a one of two cryptic species under $H$. leoparda, characterized by Cluster- 1 genotypes at 5 nuclear loci and by Clade- $I$ mitochondria

b one of two cryptic species under $H$. leoparda, characterized by Cluster- 4 genotypes at 5 nuclear loci and by Clade- $I V$ mitochondria

c original identification as H. fava by G. Yearsley and M.B. Manjaij; H. fava was then synonymised with H. undulata by Manjaji (2004)

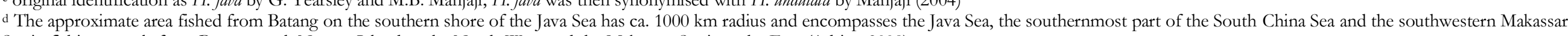

Strait; fishing vessels from Batang reach Natuna Island to the North-West and the Makassar Strait to the East (Adrim, 2008). 


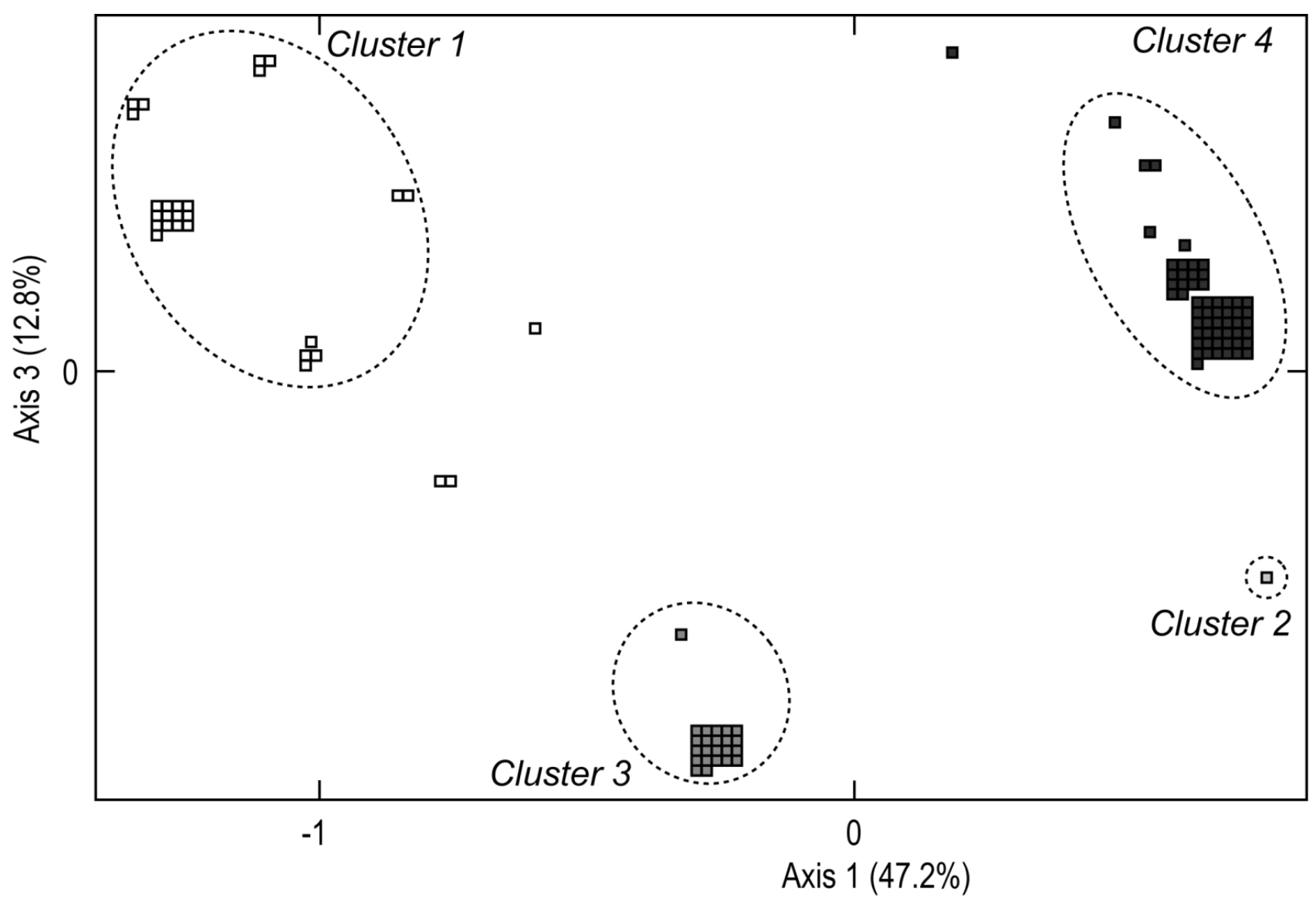

Fig. 1 Himantura narnak species complex. Correspondence analysis (CA) (GENETIX: Belkhir et al. 2000) on individuals (squares) defined by their genotypes at five polymorphic intron loci. Ellipses delineate clusters of individuals with assignment $>90 \%$ to either one of three clusters $(1,3,4)$ obtained from Bayesian structure analysis (STRUCTURE: Falush et al., 2007). 'Cluster 2' corresponds to a single individual, which was singled out on Axis 2 of CA (not shown). Individuals geometrically intermediate between Cluster 1 and either Cluster 3 or Cluster 4 were interpreted as backcross offspring (see text and Appendix 1). Mitochondrial-DNA clade of each individual (see Fig. 2) is indicated by a distinct tone of grey: open, Clade I; light grey, Clade II; dark, grey, Clade III; charcoal black, Clade IV. 


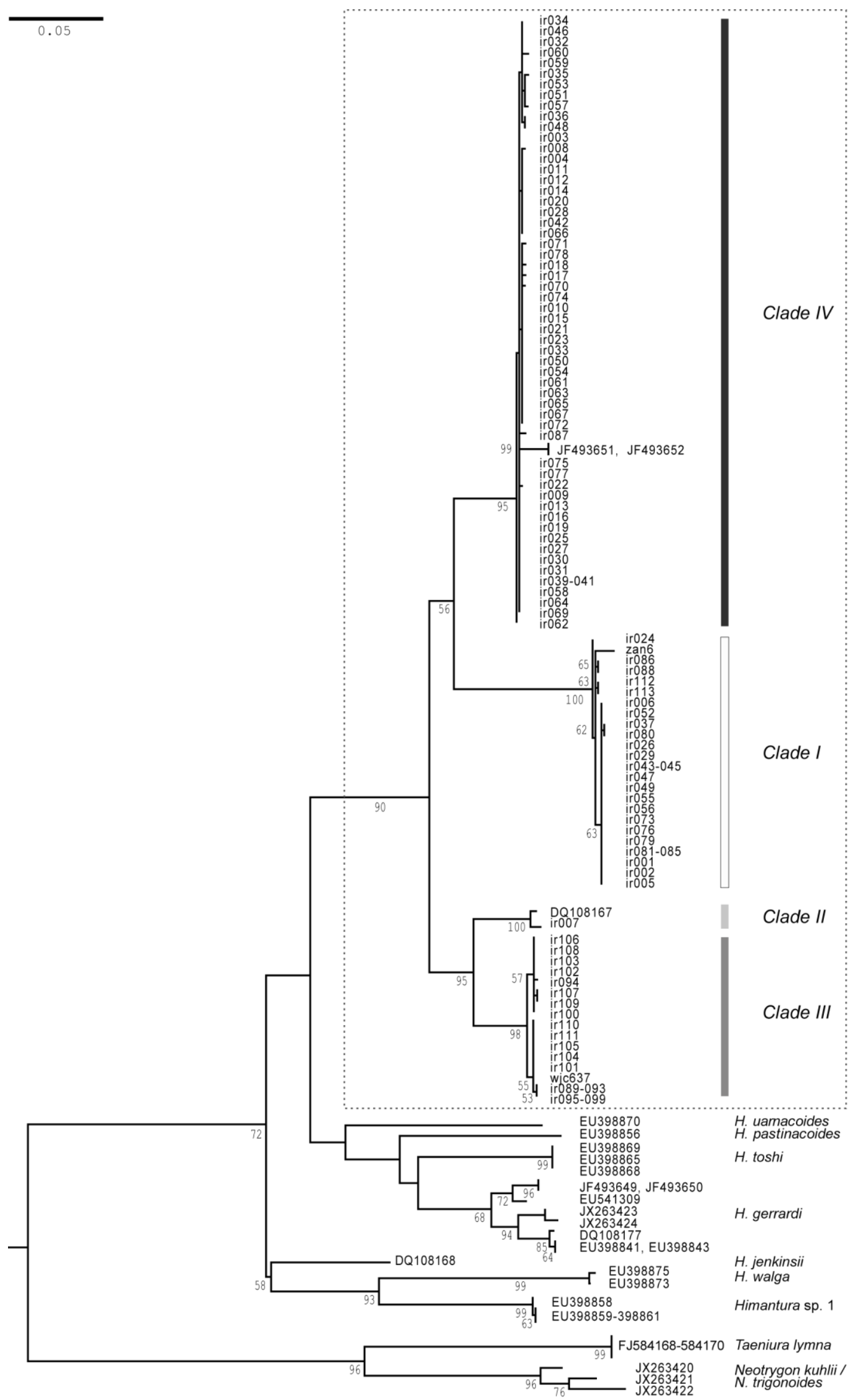

Fig. 2 Himantura narnak species complex. Maximum-likelihood phylogeny of partial COI haplotypes including all homologous sequences from Himantura spp. retrieved from GENBANK (http://www.ncbi.nlm.nih.gov/) [sequences aligned over 620 bp; Hasegawa-Kishino-Yano+G+I substitution model; 1000 bootstrap resamplings; MEga5 (Tamura et al., 2011)]. The tree was rooted by the homologous sequence in Rhynchobatus djiddensis (GENBANK JX263419). Only bootstrap scores $>50 \%$ are presented. Dotted rectangle delimitates ingroup haplotypes. 


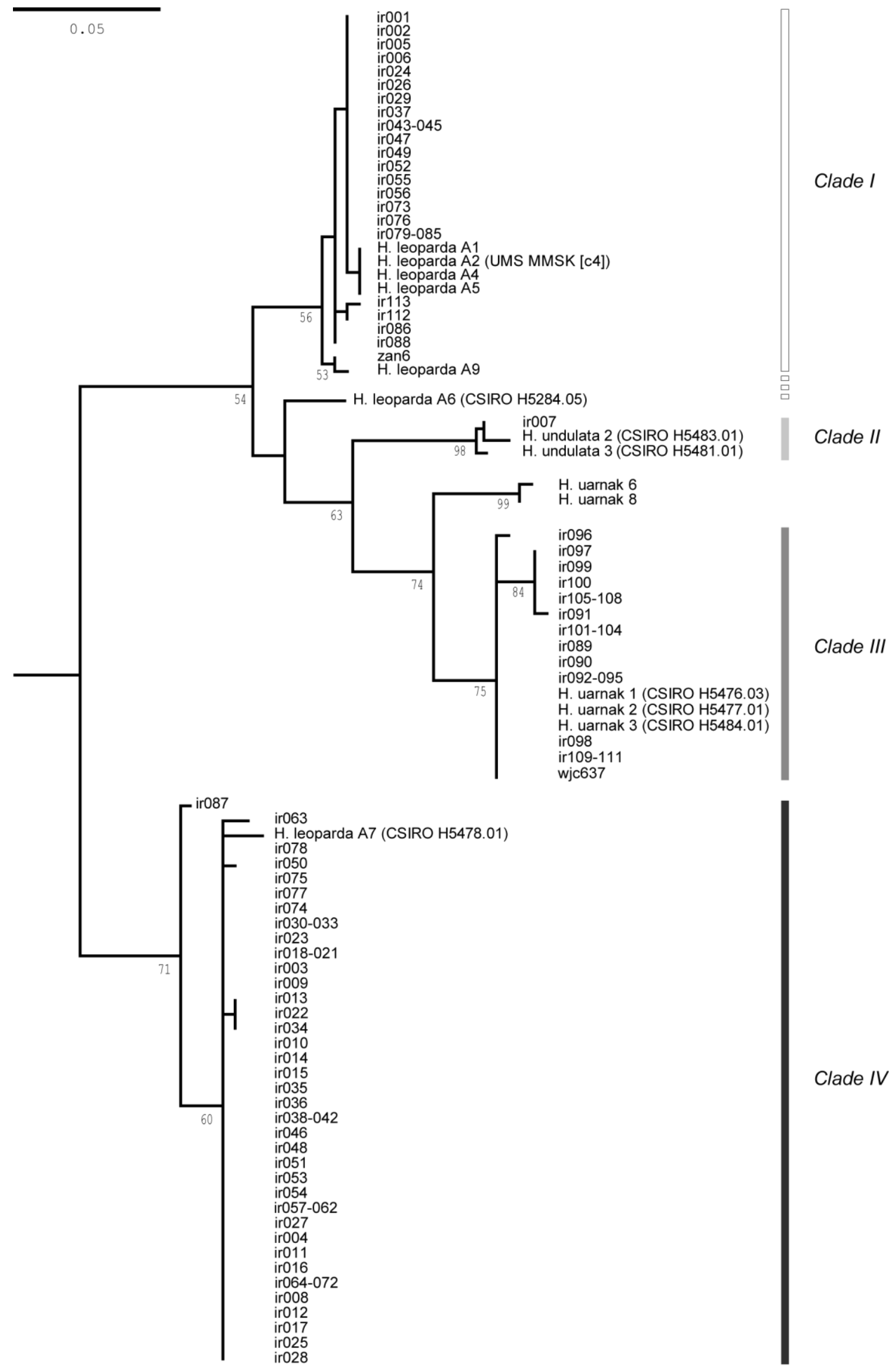

Fig. 3 Himantura narnak species complex. Maximum-likelihood tree of partial cytb sequences including homologous sequences from Manjaji (2004) [sequences aligned over 239 bp; Kimura-2 parameter model with gamma-distributed evolutionary rates among sites; 1000 bootstrap resamplings; MEGA5 (Tamura et al., 2011)]. The tree was rooted by the homologous sequence in H. signifer specimen ZRC42547 (Manjaji, 2004). Only bootstrap scores $>50 \%$ are presented. 
Table S1. Himantura narnak species complex. Genotypes and mitotype of 114 individuals, as determined from their size-alleles at 5 Mendelian-like intron loci and their nucleotide sequences at the COI and/or the cytb loci. Batang Batang, Java Sea; Sunda Sunda Strait; Makassar Makassar Strait; Selayar Bone Basin off Selayar Island, Banda Sea; Kendari Kendari, Banda Sea; Labuanbajo Labuan Bajo, Flores Sea; Bali Bali Sea; Jogyakarta off Jogyakarta, Indian Ocean coast of Java; Zanzibar Zanzibar, West Indian Ocean; Taiwan Taiwan, northwestern Pacific. Assignment of each individual to one of three clusters (1, 3, 4) was determined from Bayesian structure analysis [STRuCture: Falush et al., Mol. Ecol. Resour. 7 (2007) 574-578] of multiple-locus nuclear genotypes. The Markov-Chain Monte Carlo algorithm implemented in STRUCTURE was run under the admixture model with correlated allele frequencies for 100,000 steps after 50,000 initial burn-in steps, without any a priori information on an individual's sampling location, to estimate individual admixture proportions and assign individuals to populations. Five independent runs were performed for each a priori number of parental clusters $(K)$, ranging from 2 to 6 to infer the number of clusters by visually comparing the output diagrams. The most informative diagram was produced with $K=3$ (Fig. S1).

\begin{tabular}{|c|c|c|c|c|c|c|c|c|c|}
\hline \multirow{2}{*}{$\begin{array}{l}\text { Sample, } \\
\text { Individual no. }\end{array}$} & \multicolumn{5}{|c|}{ Nuclear locus } & \multicolumn{3}{|c|}{ Assignment probability } & \multirow[t]{2}{*}{ Mitotype } \\
\hline & Act-2A & Act-2 B & Cam-3A & Cam-3 B & Cam-3 C & Cluster 1 & Cluster 3 & Cluster 4 & \\
\hline \multicolumn{10}{|l|}{ Batang } \\
\hline ir001 & 186 & 100 & $178 / 175$ & 163 & 125 & 0.934 & 0.053 & 0.013 & $I$ \\
\hline ir002 & 186 & 100 & 178 & 163 & 125 & 0.987 & 0.009 & 0.004 & I \\
\hline ir003 & 190 & 100 & 175 & 165 & 144 & 0.004 & 0.008 & 0.988 & $I V$ \\
\hline ir004 & 190 & 100 & 175 & 165 & 144 & 0.004 & 0.008 & 0.988 & IV \\
\hline ir005 & 186 & 100 & 178 & 163 & 125 & 0.988 & 0.008 & 0.004 & $I$ \\
\hline ir006 & 186 & 100 & $178 / 175$ & 163 & 125 & 0.933 & 0.054 & 0.012 & I \\
\hline ir007 & $190 / 187$ & $100 / 097$ & 175 & 165 & $144 / 129$ & 0.008 & 0.016 & 0.976 & II \\
\hline ir008 & 190 & 100 & 175 & 165 & 144 & 0.004 & 0.008 & 0.988 & IV \\
\hline ir009 & 190 & $100 / 098$ & 175 & 165 & $144 / 129$ & 0.006 & 0.008 & 0.987 & IV \\
\hline ir010 & 190 & $100 / 098$ & 175 & 165 & 129 & 0.006 & 0.008 & 0.986 & IV \\
\hline ir011 & 190 & 100 & 175 & 165 & 144 & 0.004 & 0.008 & 0.988 & IV \\
\hline ir012 & 190 & 100 & 175 & 165 & 144 & 0.004 & 0.008 & 0.988 & IV \\
\hline ir013 & 190 & 100 & 175 & - & 144 & 0.004 & 0.008 & 0.988 & IV \\
\hline ir014 & 190 & 100 & 175 & - & 144 & 0.004 & 0.008 & 0.988 & IV \\
\hline ir015 & 190 & 100 & 175 & 165 & 144 & 0.004 & 0.008 & 0.988 & IV \\
\hline ir016 & 190 & 100 & 175 & - & 144 & 0.004 & 0.008 & 0.988 & IV \\
\hline ir017 & 190 & 100 & 175 & 165 & 144 & 0.004 & 0.008 & 0.988 & IV \\
\hline ir018 & 190 & 100 & 175 & 165 & 144 & 0.004 & 0.008 & 0.988 & IV \\
\hline ir019 & 190 & 100 & 175 & 165 & 144 & 0.004 & 0.008 & 0.988 & IV \\
\hline ir020 & 190 & 100 & 175 & 165 & 144 & 0.004 & 0.008 & 0.988 & IV \\
\hline ir021 & 190 & 100 & 175 & 165 & 144 & 0.004 & 0.008 & 0.988 & IV \\
\hline ir022 & 190 & 100 & 175 & 165 & 144 & 0.004 & 0.008 & 0.988 & IV \\
\hline ir023 & 190 & 100 & 175 & 165 & 144 & 0.004 & 0.008 & 0.988 & IV \\
\hline ir024 & 186 & 100 & $178 / 175$ & $165 / 163$ & 125 & 0.697 & 0.277 & 0.026 & $I$ \\
\hline ir025 & 190 & 100 & 175 & 165 & 144 & 0.004 & 0.008 & 0.988 & IV \\
\hline ir026 & 186 & 100 & 178 & 163 & 125 & 0.988 & 0.008 & 0.004 & $I$ \\
\hline ir027 & 190 & 100 & 175 & 165 & 144 & 0.004 & 0.008 & 0.988 & $I V$ \\
\hline ir028 & 190 & 100 & 175 & 165 & 144 & 0.004 & 0.008 & 0.988 & $I V$ \\
\hline ir029 & 186 & 100 & 178 & 163 & 125 & 0.988 & 0.008 & 0.004 & $I$ \\
\hline ir 030 & 190 & 100 & 175 & 165 & 144 & 0.004 & 0.007 & 0.988 & $I V$ \\
\hline ir031 & 190 & 100 & 175 & 165 & $144 / 129$ & 0.004 & 0.008 & 0.988 & IV \\
\hline ir032 & 190 & 100 & 175 & 165 & 144 & 0.004 & 0.008 & 0.988 & IV \\
\hline ir033 & - & 100 & - & - & - & - & - & - & IV \\
\hline ir034 & 190 & 100 & 175 & 165 & 144 & 0.004 & 0.008 & 0.988 & IV \\
\hline ir035 & 190 & 100 & 175 & 165 & $144 / 129$ & 0.004 & 0.008 & 0.988 & IV \\
\hline ir036 & 190 & 100 & 175 & 165 & $144 / 129$ & 0.004 & 0.008 & 0.988 & IV \\
\hline ir037 & 186 & 100 & $178 / 175$ & $165 / 163$ & 125 & 0.700 & 0.275 & 0.024 & I \\
\hline ir038 & 190 & 100 & 175 & 165 & 144 & 0.004 & 0.008 & 0.988 & IV \\
\hline ir039 & 190 & 100 & 175 & 165 & 144 & 0.004 & 0.008 & 0.988 & IV \\
\hline ir040 & 190 & 100 & 175 & 165 & 144 & 0.004 & 0.008 & 0.988 & IV \\
\hline ir041 & 190 & 100 & 175 & 165 & 144 & 0.004 & 0.008 & 0.988 & IV \\
\hline ir042 & 190 & 100 & 175 & 165 & 144 & 0.004 & 0.008 & 0.988 & IV \\
\hline ir043 & 186 & 100 & 178 & 163 & $129 / 125$ & 0.988 & 0.007 & 0.005 & $I$ \\
\hline ir044 & 186 & 100 & 178 & $165 / 163$ & $129 / 125$ & 0.947 & 0.033 & 0.020 & $I$ \\
\hline ir045 & 186 & 100 & 178 & 163 & $129 / 125$ & 0.988 & 0.006 & 0.005 & $I$ \\
\hline ir046 & 190 & 100 & 175 & 165 & 144 & 0.004 & 0.008 & 0.988 & IV \\
\hline ir047 & 186 & 100 & 178 & $165 / 163$ & $129 / 125$ & 0.946 & 0.034 & 0.020 & $I$ \\
\hline ir048 & 190 & 100 & 175 & 165 & $144 / 129$ & 0.004 & 0.008 & 0.988 & IV \\
\hline ir049 & 186 & 100 & 178 & 163 & 125 & 0.988 & 0.009 & 0.004 & $I$ \\
\hline ir050 & 190 & 100 & 175 & 165 & $144 / 129$ & 0.004 & 0.008 & 0.987 & IV \\
\hline ir051 & 190 & 100 & 175 & 165 & $144 / 129$ & 0.005 & 0.008 & 0.988 & IV \\
\hline ir052 & 186 & 100 & 178 & 163 & 125 & 0.988 & 0.008 & 0.004 & $I$ \\
\hline
\end{tabular}




\begin{tabular}{|c|c|c|c|c|c|c|c|c|c|}
\hline ir053 & 190 & 100 & $178 / 175$ & $165 / 163$ & 144 & 0.255 & 0.006 & 0.740 & IV \\
\hline ir054 & 190 & 100 & 175 & 165 & 144 & 0.004 & 0.008 & 0.988 & IV \\
\hline ir055 & 186 & $100 / 098$ & 178 & 163 & 125 & 0.989 & 0.007 & 0.004 & $I$ \\
\hline ir056 & 186 & $100 / 098$ & 178 & 163 & 125 & 0.989 & 0.007 & 0.004 & $I$ \\
\hline ir057 & 190 & 100 & 175 & 165 & 129 & 0.005 & 0.008 & 0.987 & IV \\
\hline ir058 & 190 & 100 & 175 & 165 & 144 & 0.004 & 0.008 & 0.988 & IV \\
\hline ir059 & 190 & 100 & 175 & 165 & $144 / 129$ & 0.004 & 0.008 & 0.988 & IV \\
\hline ir060 & 190 & 100 & 175 & 165 & $144 / 129$ & 0.004 & 0.008 & 0.988 & IV \\
\hline ir061 & 190 & 100 & 175 & 165 & 144 & 0.004 & 0.008 & 0.988 & IV \\
\hline ir062 & 190 & 100 & 175 & 165 & 144 & 0.004 & 0.008 & 0.988 & IV \\
\hline ir063 & 190 & 100 & 175 & 165 & 144 & 0.004 & 0.008 & 0.988 & IV \\
\hline ir064 & 190 & 100 & 175 & 165 & $144 / 129$ & 0.004 & 0.008 & 0.988 & IV \\
\hline ir065 & 190 & $100 / 098$ & 175 & 165 & $144 / 129$ & 0.006 & 0.008 & 0.987 & IV \\
\hline ir066 & 190 & 100 & 175 & 165 & $144 / 129$ & 0.004 & 0.008 & 0.988 & IV \\
\hline ir067 & 190 & 100 & 175 & 165 & $144 / 129$ & 0.004 & 0.008 & 0.988 & IV \\
\hline ir068 & - & 100 & - & - & - & - & - & - & IV \\
\hline ir069 & $192 / 190$ & 100 & 175 & 165 & $144 / 129$ & 0.006 & 0.012 & 0.982 & IV \\
\hline ir070 & 190 & 100 & 175 & 165 & $144 / 129$ & 0.004 & 0.008 & 0.988 & IV \\
\hline ir071 & 190 & 100 & 175 & 165 & 144 & 0.004 & 0.008 & 0.988 & IV \\
\hline ir072 & 190 & 100 & 175 & 165 & $144 / 129$ & 0.004 & 0.008 & 0.987 & IV \\
\hline ir073 & 186 & 100 & 178 & 163 & 125 & 0.988 & 0.008 & 0.004 & $I$ \\
\hline ir074 & 190 & 100 & 175 & 165 & $144 / 129$ & 0.004 & 0.008 & 0.988 & IV \\
\hline ir075 & - & $100 / 098$ & 175 & 165 & - & - & - & - & IV \\
\hline ir076 & - & 100 & 178 & 163 & 125 & 0.988 & 0.008 & 0.004 & $I$ \\
\hline ir077 & 190 & 100 & 175 & 165 & 144 & 0.004 & 0.008 & 0.988 & IV \\
\hline ir078 & 190 & 100 & 175 & 165 & 144 & 0.004 & 0.008 & 0.988 & IV \\
\hline ir079 & 186 & 100 & $178 / 175$ & 163 & 125 & 0.934 & 0.053 & 0.013 & $I$ \\
\hline ir080 & - & 100 & - & - & - & - & - & - & $I$ \\
\hline ir081 & 186 & 100 & 178 & 163 & $129 / 125$ & 0.988 & 0.007 & 0.005 & $I$ \\
\hline ir082 & 186 & 100 & 178 & $165 / 163$ & 125 & 0.935 & 0.053 & 0.012 & $I$ \\
\hline ir083 & 186 & 100 & $178 / 175$ & $165 / 163$ & $129 / 125$ & 0.789 & 0.150 & 0.061 & $I$ \\
\hline ir084 & 186 & 100 & 178 & 163 & 125 & 0.988 & 0.008 & 0.004 & $I$ \\
\hline ir085 & - & 100 & - & - & - & - & - & - & $I$ \\
\hline \multicolumn{10}{|l|}{ Sunda } \\
\hline ir086 & 186 & 100 & 178 & 163 & 125 & 0.987 & 0.008 & 0.004 & I \\
\hline ir087 & 190 & 100 & 175 & 165 & 144 & 0.004 & 0.008 & 0.988 & IV \\
\hline ir088 & 186 & 100 & 178 & 163 & 125 & 0.988 & 0.008 & 0.004 & $I$ \\
\hline \multicolumn{10}{|l|}{ Makassar } \\
\hline ir089 & 186 & 100 & 175 & 165 & 125 & 0.008 & 0.984 & 0.008 & III \\
\hline ir090 & 186 & 100 & 175 & 165 & 125 & 0.008 & 0.984 & 0.008 & III \\
\hline ir091 & 186 & 100 & 175 & 165 & 125 & 0.008 & 0.984 & 0.008 & III \\
\hline ir092 & 186 & 100 & 175 & 165 & 125 & 0.008 & 0.984 & 0.008 & III \\
\hline ir093 & 186 & 100 & 175 & 165 & 125 & 0.008 & 0.984 & 0.008 & III \\
\hline ir094 & 186 & 100 & 175 & 165 & 125 & 0.008 & 0.984 & 0.008 & III \\
\hline ir095 & 186 & 100 & 175 & 165 & 125 & 0.008 & 0.984 & 0.008 & III \\
\hline ir096 & 186 & 100 & 175 & 165 & 125 & 0.008 & 0.984 & 0.008 & III \\
\hline ir097 & 186 & 100 & 175 & 165 & 125 & 0.008 & 0.984 & 0.008 & III \\
\hline ir098 & 186 & 100 & 175 & 165 & 125 & 0.008 & 0.984 & 0.008 & III \\
\hline ir099 & 186 & 100 & 175 & 165 & 125 & 0.008 & 0.984 & 0.008 & III \\
\hline \multicolumn{10}{|l|}{ Selayar } \\
\hline ir100 & 186 & 100 & 175 & 165 & 125 & 0.008 & 0.984 & 0.008 & III \\
\hline ir101 & 186 & 100 & 175 & 165 & 125 & 0.008 & 0.984 & 0.008 & III \\
\hline ir102 & 186 & 100 & 175 & 165 & 125 & 0.008 & 0.984 & 0.008 & III \\
\hline ir103 & 186 & 100 & 175 & 165 & 125 & 0.008 & 0.984 & 0.008 & III \\
\hline ir104 & 186 & 100 & 175 & 165 & 125 & 0.008 & 0.984 & 0.008 & III \\
\hline ir105 & 186 & 100 & 175 & 165 & 125 & 0.009 & 0.984 & 0.008 & III \\
\hline ir106 & 186 & $100 / 098$ & 175 & 165 & 125 & 0.050 & 0.924 & 0.026 & III \\
\hline \multicolumn{10}{|l|}{ Kendari } \\
\hline ir107 & 186 & 100 & 175 & 165 & 125 & 0.008 & 0.984 & 0.008 & III \\
\hline ir108 & 186 & 100 & 175 & 165 & 125 & 0.008 & 0.984 & 0.008 & III \\
\hline ir109 & 186 & 100 & 175 & 165 & 125 & 0.008 & 0.984 & 0.008 & III \\
\hline \multicolumn{10}{|c|}{ Labuanbajo } \\
\hline ir110 & 186 & 100 & 175 & 165 & 125 & 0.008 & 0.984 & 0.008 & III \\
\hline ir111 & 186 & 100 & 175 & 165 & 125 & 0.008 & 0.984 & 0.008 & III \\
\hline \multicolumn{10}{|l|}{ Bali } \\
\hline ir112 & 186 & 100 & 178 & 163 & 125 & 0.988 & 0.008 & 0.004 & $I$ \\
\hline \multicolumn{10}{|l|}{ Jogyakarta } \\
\hline ir113 & 186 & $100 / 098$ & 178 & 163 & 125 & 0.989 & 0.007 & 0.004 & $I$ \\
\hline \multicolumn{10}{|l|}{ Zanæibar } \\
\hline zan6 & 186 & 100 & 178 & 163 & 125 & 0.988 & 0.009 & 0.004 & $I$ \\
\hline Taiwan & & & & & & & & & \\
\hline wjc637 & - & - & - & - & - & - & - & - & III \\
\hline
\end{tabular}




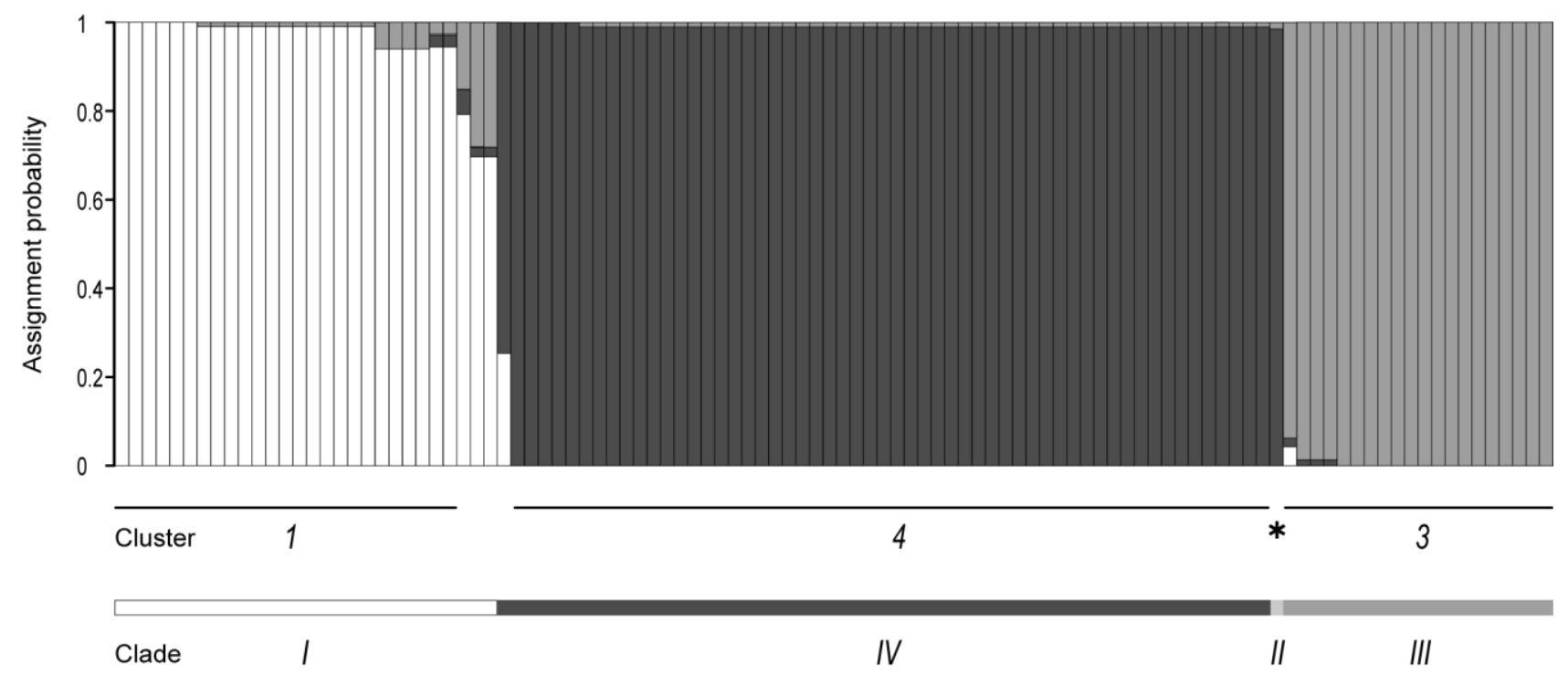

Fig. S1. Himantura uarnak species complex. Output diagram of Bayesian population structure analysis [STRUCTURE: Falush et al., Mol. Ecol. Resour. 7 (2007) 574-578] when the number of parent populations is $K=3$. Individual probabilities of assignment are shown on the $\mathrm{y}$-axis. Individuals are represented by vertical bars and sorted by mitotype (Clades $I-I V$ ). Individual ir007, of a distinct cluster according to correspondence analysis [GENETIX: http://www.genetix.univ-montp2.fr/], is marked by an asterisk. Horizontal black traits underline individuals with $>90 \%$ assignment probability to a cluster $(1,3$, or 4$)$. 